\title{
電源系統の事故波及防止システムの方式と構成
}

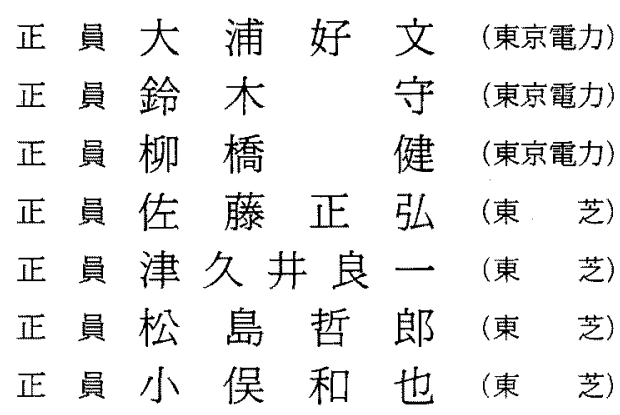

\section{Approach and Structure of Stabilizing Control System Preventing an Extension of Loss of Synchronism}

Yoshifumi Ōura, Member, Mamoru Suzuki, Member, Ken Yanagihashi, Member (Tokyo Electric Power Co.), Masahiro Sato, Member, Ryouichi Tsukui, Member, Tetsuro Matsushima, Member, Kazuya Omata, Member (Toshiba corporation)

Recently large capacity power stations have been built far from load center with long distance transmission lines. Therefore, if a fault occurs at the line, generators in the large capacity power station may lose synchronism from the remaining generators ${ }^{(1)(3)}$. To prevent an extension of loss of synchronism to other generators, fast shedding of some generators is effective measures.

Following methods were proposed so far. One ${ }^{(3)}$ is based on energy function approach. The other ${ }^{(2)}$ estimates and predicts the relative swing among generators using data measured on-line at each generator and sheds some generators for stabilization. Therefore this method requires a large communication network for an exchange of data between power stations. This paper presents new stabilizing method and newly developed stabilizing control system which does not require a large communication network because it utilizes generator output, voltage and current measured on-line in the vicinity of the large capacity power station. Using these measured data, the system estimates and predicts relative swing between generators in the large capacity power station and the remaining generators. Finally the number of generators to be shed for stabilization is decided and shedding is performed. Configuration and characteristics of the developed stabilizing control system are shown. Validity of this method is confirmed by simulation and testing using an artificial power system.

キーワート゚: 電力系統, 過渡安定度, 安定化, オンライン, 電源制限, 実用化システム

\section{1.まえがき}

最近の電力系統では大容量発電所 (電源系発電所)が 負荷中心加ら遠方に建設され，長距離送電線(電源線) で接続されている。このために，3LGなどの事故に より電源系発電機が脱調し,ひいては大規模停電事故
に発展することが懸念されている。ここで対象とする 現象は，電源線に発生した事故により，電源系の発電 機群が一体となり加速し，その位相角が主幹系統側の 各発電機よりも大きく進み 1 秒前後で脱調するパター ンである。この対策には電源系の一部の発電機を高速 に解列する電源制限が有効である(1)(3)。 
文献 (3)には電源線事故時の安定化のために，エネ ルギー関数法の考え方に基づく方式が提案されてい

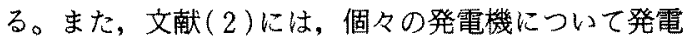
機出力を時々刻々と測定し，運動方程式加方位相角を 推定し発電機間の相対的な動摇を把握することによっ て脱調予測・安定化する方式が提案されている。これ に対して，本論文で提案する方式は次のように行う。 まず，主幹系統側の発電機群は一団となり動摇するの で，その影響を反映する位相角を仮想ノードの電圧位 相角として推定する。具体的には, 電源系発電機近傍 の母線電圧と電源線電流を実測し，インピーダンスと の関係加算出する。一方，電源系発電機の位相角変 化は測定した発電機出力を用いて推定する。次に，安 定度判定は, 電源系発電機群の位相角と仮想ノードの 電圧位相角について，過去の動摇状態を基に約 250 三 リ秒の将来時点までの変動を予測し，両者の相対的な 位相角動摇を見て行う。不安定が予想される場合, 発 電機の解列台数を高速・高精度に決定し, 解列するこ とにより事故波及を防止させるものである。

文献 (2)の方式は, 個々の発電機動摇を直接観測す るので，遠方の発電機間のデータ伝送系を必要とする が，本論文で提案する方式は，対象とする電源系発電 所の近傍で測定できるデータのみを用いるので安定化 システム・伝送系が小規模となることが長所である。 本方式に基づく安定化システムを数セット開発した。

以下，第 2 章では動摇現象の把挃の方法，第 3 章で は安定化の方式・アルゴリズムを示す。第 4 章ではシ ミュレーションにより確認した手法の有効性を示す。 第 5 章では, 本安定化システムには, 約 1 秒で脱調す る系統現象をリアルタイムで追随し観測・制御するた めに高速なデータサンプリング，伝送，演算を行うこ とが要求されているが，これを実現するために開発し たシステムの構成・機能を述べる。第 6 章に本システ ムを模擬送電系統で試験した結果を示す。

\section{2. 動摇現象の把握法}

電源系の発電機群が一体となり，主幹系統側の発電 機群と相対的に動摇するパターンを考える。図1にお いて，電源系の発電機群を等価発電機 $G_{1}$ と表す。 $G_{1}$ は長距離送電線を介して接続されている。この場合, 事故が長距離送電線に発生したときの各発電機の動摇 を見れば，図 2 に示すように，G めに大きく加速されるが，主幹系統側の $G_{2}$ から $G_{n}$ までの発電機群は同期化力が強く, 同じ様相(コヒー レント)で動摇する。この結果, 両者の位相角差は拡 大する。また，主幹系統内に属する負荷ノードの電圧

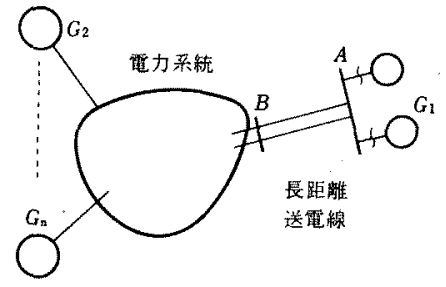

図 1 系統モデル

Fig. 1. Power system model.

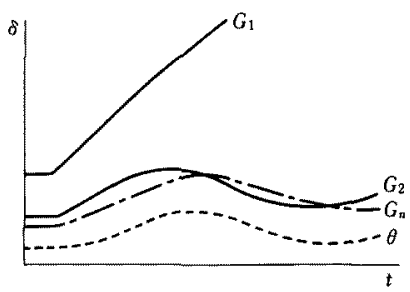

図 2 動摇モード

Fig. 2. Typical swing mode.

位相角 $\theta$ は, 発電機 $G_{2}$ から $G_{n}$ の影響を大きく受け て図 2 の破線のように $G_{2}$ から $G_{n}$ と同じ様相で動摇 する。この性質を利用することによって $G_{1}$ と残りの $G_{2}$ から $G_{n}$ までの発電機群との間の相対的な動摇を 把握し安定化する方法を考える。

まず，上記関係を用いた安定度判定を行うためのモ デルについて述べる。電源線の電流の変化は電源側の 発電機の内部電圧と主幹系統の母線電圧の間の位相角 差の変化を反映している。そこで，図1の対象系統も デルに扔いて，電源線上のノードBから系統を見た 駆動点インピーダンス $\dot{Z}_{s c}$ 求め $\dot{Z}_{s c}$ 背後のノード $S$ を仮想ノードとすれば，ノード $S$ の電圧 $\dot{V}_{s}$ が $G_{2}$ か ら $G_{n}$ の動摇を反映する。ここで，ノード $A$ と $B$ の 間の線路インピーダンス $\dot{Z}_{A B}$, 発電機 $G_{1}$ の発電機電

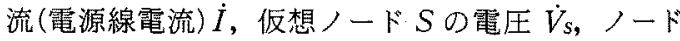
$A$ の電压 $\dot{V}_{A}$, そして発電機 $G_{1}$ の内部電圧 $\dot{V}_{G}$ の関 係を，図3のモデル系統で考えることができ，図 4 て 表すことができる。 $\dot{V}_{C} ， \dot{V}_{S}$ は $\dot{V}_{A} ， \dot{I}$ を測定すれば， 発電機の内部インピーダンス $\dot{X}_{s}$, 発電機の主変圧器 のインピーダンス $\dot{X}_{t}$ などを用いて (1)，(2)式で計 算でき，電源線電流 $\dot{I}$ は $\dot{V}_{G}$ と $\dot{V}_{S}$ 間の相対位相角を 反映し変化する。ここで， $\delta_{G}$ は $\dot{V}_{G}$ と $\dot{V}_{A}, \delta_{S}$ は $\dot{V}_{A}$ と $\dot{V}_{S}$ 間の相対位相角差を示す。また，図 5 の実線と 破線で示すように $\dot{V}_{G}, \dot{V}_{A}, \dot{V}_{S}$ 間の関係は事故発生 前 $t_{0}$ 時点と事故除去後 $t$ 時点においても成立するの で，事故発生後の $\delta_{G} ， \delta_{5}$ の変化を時々刻々と観测す ることによって, 発電機 $G_{1}$ と残りの発電機群との間 


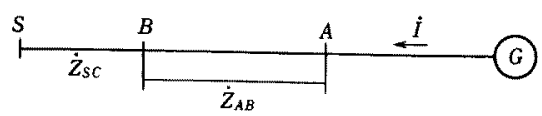

図 3 簡易モデル

Fig. 3. Simplified model.

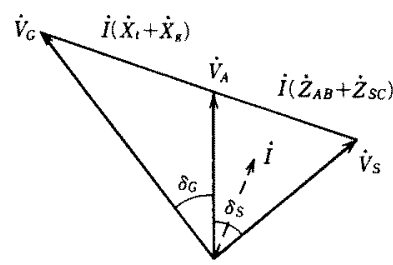

図 4 簡易モデルの位相角の関係

Fig. 4. Relation between $\dot{V}_{C}$ and $\dot{V}_{S}$ in the simplified model.

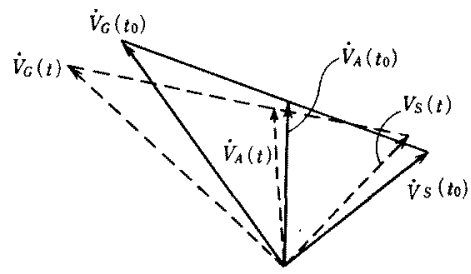

図 5 位相角の変動

Fig. 5. Change of phase angles.

の相対的な動摇を把握することができる。たた゚し，事 故中とその直後は発電機内部電圧は過渡的なインピー ダンス変化の影響を受けるので $\delta_{G}$ は発電機出力を用 いて第 3 章に示す方法で観測する。

$$
\begin{aligned}
& \dot{V}_{C}=\dot{V}_{A}+\dot{I}\left(\dot{X}_{t}+\dot{X}_{g}\right) \\
& \dot{V}_{s}=\dot{V}_{A}-\dot{I}\left(\dot{Z}_{A B}+\dot{Z}_{s c}\right)
\end{aligned}
$$

この方式によれば，主幹系統側の個々の発電機動摇 を直接観測せずに，それらの動摇を反映している位相 角を仮想ノードの電圧位相角として推定し，それと電 源側の発電機 $G_{1}$ の内部電圧との位相角差をみて判定 することになる。

以下，時間変化を示す量には $(t)$ で記す。

\section{3. 安定化方式}

$\delta_{c}(t), \delta_{s}(t)$ の求め方は, 次の手順で行う。まず, 発電機 $G$ の慣性を $M$, 事故前の $G$ の出力を $P_{0}$ とす ると, 事故発生後サンプリングして得た発電機出力值 $P(t)$ を用いて ( 3$) \sim(6)$ 式により, 角速度 $\omega(t)$, 位 相角 $\delta_{G}(t)$ が計算できる。

$$
\begin{aligned}
& t_{k+1}=t_{k}+\Delta t \\
& \Delta \omega\left(t_{k}\right)=\left\{P_{0}-P\left(t_{k}\right)\right\} t / M
\end{aligned}
$$

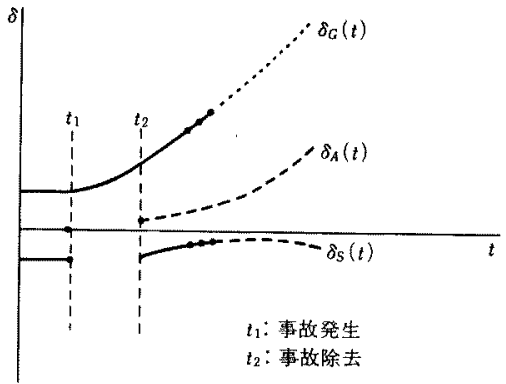

図 6 位相角動摇の実測值と予測値の関倸

Fig. 6. Relation between measured value and predicted value of phase angle.

$$
\begin{aligned}
& \omega\left(t_{k+1}\right)=\omega\left(t_{k}\right)+\Delta \omega \ldots \ldots \ldots . \\
& \delta_{G}\left(t_{k+1}\right)=\delta_{G}\left(t_{k}\right)+\omega\left(t_{k+1}\right) \Delta t
\end{aligned}
$$

次に，仮想ノード $S$ の電圧 $\dot{V}_{s}$ は夷測した発電機電 流 $\dot{I}$ と $\dot{V}_{A}$ を用い(2)式加計算する。 $\delta_{S}(t)$ は $\dot{V}_{S}$ 加求められる。この結果, $\dot{V}_{G}, \dot{V}_{A}, \dot{V}_{S}$ は図 5 の ように，実線で示す初期值から破線で示す $t$ 時点のべ クトルに推移する。また, 発電機の位相角 $\delta_{\sigma}(t)$ と, ノード電圧の位相角 $\delta_{A}(t), \delta_{S}(t)$ は事故発生前後にお いて図 6 に示すように変化する。ただし，事故継続中 の電圧位相角は，事故中のインピーダンス変化の影響 を受けるため不連続になり，また事故除去直後は過渡 状態があるので，そこを除いた時間带において観測し た值を用いる。

また, 発電機の位相角 $\delta_{G}(t)$ の予測は次式で行 $j^{(1)(2)}$ 。発電機は慣性が大きいため角速度 $\omega(t)$ は滑 ら加に変動するので，過去数点の $\omega(t)$ を通る曲線を 求め，その延長上の点としての予測值を求める方法を 採った。現時点 $t_{0}, 1$ 時点前 $t_{1}, 2$ 時点前 $t_{2} の \omega\left(t_{0}\right)$, $\omega\left(t_{1}\right), \omega\left(t_{2}\right)$ を通る $\omega(t)$ の曲線を( 7$)$ 式で求める(4)。

$$
\omega(t)=\omega\left(t_{2}\right)+\alpha_{1}\left(t-t_{2}\right)+\alpha_{2}\left(t-t_{1}\right)\left(t-t_{2}\right)
$$

ここで, 係数 $\alpha_{1}, \alpha_{2}$ は (8) 式で決める。

$$
\left.\begin{array}{l}
\alpha_{1}=\left\{\omega\left(t_{2}\right)-\omega\left(t_{1}\right)\right\} /\left(t_{2}-t_{1}\right) \\
\alpha_{0}=\left\{\omega\left(t_{1}\right)-\omega\left(t_{0}\right)\right\} /\left(t_{1}-t_{0}\right) \\
\alpha_{2}=\left(\alpha_{1}-\alpha_{0}\right) /\left(t_{2}-t_{0}\right)
\end{array}\right\}
$$

次に $\delta$ の推定式は (7) 式を積分した次式となる。

$$
\begin{aligned}
\delta_{G}(t)= & \delta_{G}\left(t_{0}\right)+\omega\left(t_{2}\right)\left(t-t_{0}\right) \\
& +\alpha_{1}\left\{\left(t^{2}-t_{0}^{2}\right) / 2-t_{2}\left(t-t_{0}\right)\right\} \\
& +\alpha_{2}\left\{\left(t^{3}-t_{0}^{3}\right) / 3-\left(t_{0}+t_{2}\right)\left(t^{2}-t_{0}^{2}\right) / 2\right. \\
& \left.+t_{1} t_{2}\left(t-t_{0}\right)\right\} \cdots \cdots \cdots \cdots \cdots \cdots \cdots \cdots \cdots \cdots \cdots \cdots \cdots \cdots \cdots \cdots \cdots
\end{aligned}
$$

また, 電圧 $V_{s}$ の位相角 $\delta_{s}(t)$ の予測は $t_{0}, t_{1}, t_{2}$ 時点 の $\delta_{s}\left(t_{0}\right), \delta_{s}\left(t_{1}\right), \delta_{s}\left(t_{2}\right)$ を用い，(7)，(8)式と同様 
に定義した式で行う。

以上の計算加ら求め大予测值 $\delta_{C}(t)$ と $\delta_{S}(t)$ の位相 角差分 $\Delta \delta G s(t)$ が発散傾向を示し，かつ，あるしきい 值以上の值になれば脱調と判定する(1)(2)。

脱調するケースを安定化するために解列する発電機 台数の決定法を次に示す(1)(2)。まず，ある時点切にお いて，将来の $T_{P}$ 時点の位相角差分 $\Delta \delta_{G S}\left(T_{P}\right)$ 予测 する。次に， $T_{P}$ より短い将来時点 $T_{C}$ に扔いて発電 所 $G$ の $n$ 台の発電機中 $m$ 台を解列すれば， $T_{P}$ 時点 の位相角䗆定僋に $\Delta \delta\left(T_{P}\right)$ だけ回復し $\Delta \delta_{C S}{ }^{*}\left(T_{P}\right)$ と なる。

$$
\Delta \delta_{C S} *\left(T_{P}\right)=\Delta \delta_{G S}\left(T_{P}\right)+\Delta \delta\left(T_{P}\right)
$$

ここで, 回復量 $\Delta \delta\left(T_{P}\right)$ の求め方を示す。まず, 時 間のオーダを示すと， 1 秒程度で脱調する現象であ り，まな安定な場合の振動周期は 1 秒程度なので から 0.25 秒程度の将来までの位相角を精度良く予湘 できる(2)。また， $T_{c}$ は安定化システムの計算時間， リレー, 遮断器の応動学め 00 約 0.08 秒後であ る。従って， $T_{C}$ から $T_{P}$ までの間隔は 0.2 秒程度の 短時間なので, その間の電気出力値は $\tau_{0}$ 時点の値 $P\left(\tau_{0}\right)$ に等しいものと近似でるる。それゆえ, 解列な しの場合 $T_{C}$ 加 $T_{P}$ までの位相角堌加分 $\Delta \delta_{1}$ は次式 で求められる(2)。

$$
\Delta \delta_{1}=\left\{P_{0}-P\left(\tau_{0}\right)\right\}\left(T_{P}-T_{C}\right)^{2} / 2 M
$$

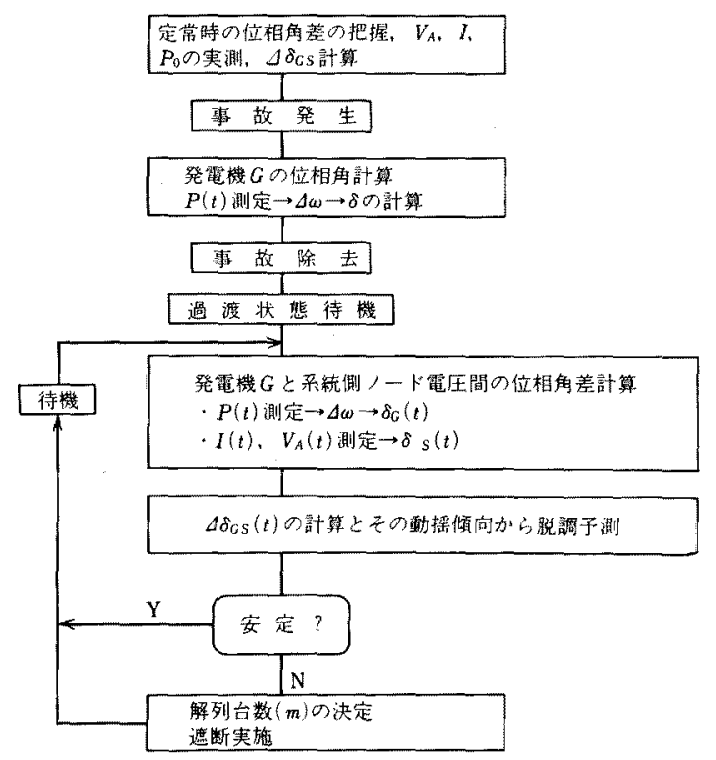

図 7 安定度判定と対策の流れ

Fig. 7. Flow for predicting instability and stabilizing procedure.
また，同一所内の発電機 $n$ 台のうち $m$ 台安解列し たとき， $m$ 台解列後の慣性と機械入力は备々容量比 で変化し各々 $M^{*}, P_{C}{ }^{*}$ となる。更に, 電気出力 $P^{*}$ は次式で推定できる(2)。

$$
P^{*}=\frac{X_{G}+X_{D}}{X_{G}+(n-m / n) X_{D}} \frac{n-m}{n} P\left(T_{c}\right)
$$

ここで， $X_{G} ， X_{D}$ はそれぞれ $m$ 台解列前の発電機内 部インピーダンスと系統側を見た駆動点インピーダン スである。琎って， $T_{C}$ から $T_{P}$ までの位相角增加分 $\Delta \delta_{2}$ は (13)式で求められる。

$$
\Delta \delta_{2}=\left(P_{C}{ }^{*}-P^{*}\right)\left(T_{P}-T_{C}\right)^{2} / 2 M^{*}
$$

$こ 0$ 結果, 回復分 $\Delta \delta\left(T_{P}\right)$ は次式加求められる。

$$
\Delta \delta\left(T_{P}\right)=\Delta \delta_{2}-\Delta \delta_{1}
$$

$\Delta \delta\left(T_{P}\right)$ を(10)式に代入して, 相対位相角差 $\Delta \delta G \delta^{*}\left(T_{P}\right)$ を求め, 解列する台数の決定を行う。具体 的には， $(m-1)$ 台解列のときは脱調するが， $m$ 台を 解列したときには安定となるならば， $m$ 台を解列す る台数と決定する。

以上をましめた好理の流れを図 7 に示す。

\section{4. シミュレーションによる有効性の確認}

図 8 の 機系モデル系統と発電機数約 70 機の実規 模モデル系統を用いて本安定化方式の有効性を㭘証し to

図 8 の 機系モデル系統に扔いて， $G_{1}$ が対象発電 所であり複数台の同一容量発電機が立列運転してい る。そして，これらの発電機は長距離送電線 $B-5$ を 介して主幹系統に接続されている。一方，主幹系統内 発電所 $G_{2} \sim G_{4}$ 岋比較的短い送電線 $(B-5 \sigma 1 / 2 \sim 1 / 4$ のインピーダンス)により連系しており, 互いの同期 化力は強い。このような状態で，B-5に三相地絡事 故が発生すると，発電状態によっては，G 幹系統内発電所 $G_{2} \sim G_{4}$ に対して脱調する。以下, $G_{1}$

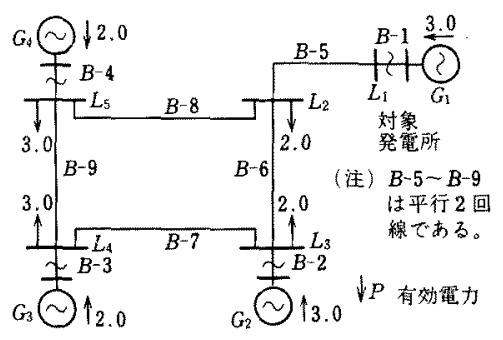

図 84 機系モデル系統

Fig. 8. Model power system with 4 generators. 
の一部の発電機を解列して安定化するので $G$ を制御 対象発電所と呼ぶこととする。

$\langle 4 \cdot 1\rangle$ 発電機, 負荷の位相角と $\theta_{S}$ の関係 図 8 のモデル系統に対するシミュレーション結果を図 9 に 示す。

(a) 図は安定なケースである。一方，(b)図は不安 定なケースであり，0.8秒前後で $G_{1}$ が脱調する。同 図からわかるように，仮想ノードSの電圧位相角 $\theta_{s}$ は, 主幹系統内の発電機, 負荷の位相角とコヒーレン トな動きをしており，その大きさは，主幹系統内の負 荷ノードの電圧位相角とほほ等しくなっている。

また，図10は実規模モデル系統を用いたシミュレ ーション結果の一例であり不安定なケースである。

同図に扔いては， $\delta_{A}$ 長距離送電線を介して主幹系 統に接続している発電機の内部位相角, $\delta_{B}, \delta_{C}$ は主 幹系統内の各地域を代表する発電機の内部位相角, $\theta_{D}$ は主幹系統のほほ中央に位置する大容量負荷が接

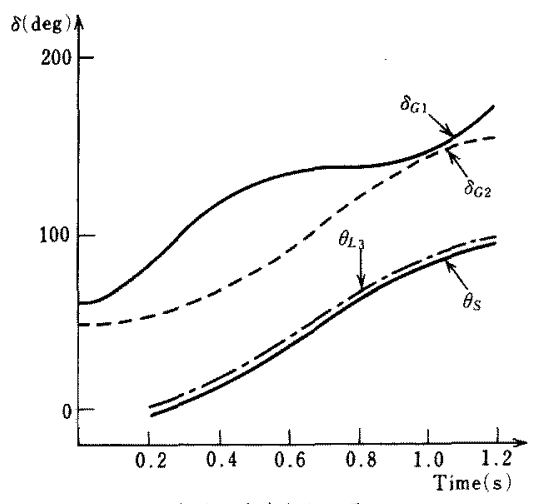

(a) 定なッース

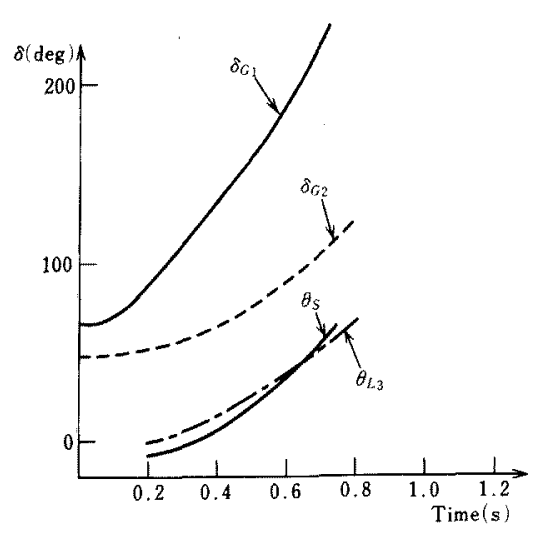

(b) 不安定なケース

図 9 発電機, 負荷の位相角と $\theta_{s}$ の関係

Fig. 9. Relation among generator angle and load angle and $\theta_{s}$.

電学論B, 112 巻 7 号, 平成 4 年
続する変電所の母線電圧位相角である。

同図からかかるように，実規模モデル系統でも，仮 想ノード $S$ の電圧位相角 $\theta_{S}$ は，主幹系統内の発電機 とコヒーレントな動きをして抢り，その值は，主幹系 統中央の変電所の母線電圧位相角とほほ一致してい る。

以上の結果は, 制御対象発電所と仮想ノード $S$ の 相対的な位相角動摇を把握することが，制御対象発電 機と主幹系統側の発電機群の相対的な位相角動摇を把 握することに有効であることを示している。

〈4・2〉安定化方式のシミュレーション結果

図 804 機系モデル系統を対象とした本安定化方式 のシミュレーション結果を示す。同図のモデル系統に 扔いて，G，菠制御対象発電所である。様々な運転状 態のもとで本安定方式が的確に応動することを確認す るため, 発電所 $G_{1}$ 内の発電機の定格出力を一律 0.5 $\mathrm{pu}$ とし, その運転台数, 初期出力, 容量 (定格出力) および $G_{2} \sim G_{4}$ の運転状態を変えて以下に示すパター ン $P_{1} \sim P_{6}$ を設定した。

$\left(P_{1}\right)$ 基本パターン。 $G_{1}$ の運転台数は 6 台で, すべて定格出力運転である。また $G_{2} \sim G_{4}$ も 定格出力運転で，その初期出力はそれぞれ $3.0 ， 2.0 ， 2.0 \mathrm{pu}$ である。

$\left(P_{2}\right) \quad G_{1}$ の運転台数を 5 台に減らしたケース。

$\left(P_{3}\right) \quad G_{1}$ の運転台数を 4 台としたケース。

$\left(P_{4}\right) \quad G_{1}$ の運転台数を 7 台に増やしたケース。

$\left(P_{5}\right) \quad G_{1}$ の運転台数, $G_{1} \sim G_{4}$ の初期出力を $P_{1}$ と全く同じとし， $G_{1}$ の運転状態を $75 \%$ 負荷 運転としたケース。

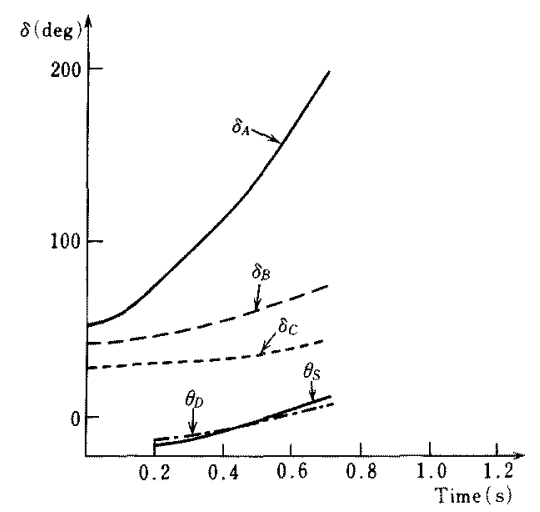

図 10 発電機, 負荷の位相角と $\theta_{S}$ の関係 (実規模モデル系統での例)

Fig. 10. Relation among generator angle and load angle and $\theta_{s}$ in real power system model. 
$\left(P_{6}\right) \quad G$, の運転台数, 初期出力を $P_{1}$ と同じと し， $G_{2} \sim G_{4}$ の運転状態を $75 \%$ 負荷運転に変 更したケース。

事故住, $B-501$ 回線 $3 \mathrm{LG}$ 主保護遮断事故(事故 継続時間 70 ミリ秒)に限定し, 安定化システムの応動 時間は, 安定度の判定と発電機の解列台数を決定する 時点が事故発生後 150 ミリ秒, そして, 発電機解列時 点が事故発生後 250 ミリ秒とした。

表 1 に各パターンに対する無対策時の現象と，本安 定化方式による発電機解列台数扝よび試行錯誤により 求めた安定化に必要な最小解列台数を示す。表 1 から わかるように，本安定化方式による解列台数は，全ケ 一ス最小解列台数と一致している。

表 1 のシミュレーション結果をまとめると次のよう になる。

（1）ケース1からケース50結果より, 本安定化 方式は, 対象発電所の運転状態(発電機運転台数やそ の負荷状態)の変化による安定度度合の差を的確に上 らえ, 解列台数を算出することがわかる。これは, 本 方式が, 対象発電所の位相角動摇を常時把握している ためで, 運転状態の変化による安定度度合の変化は, 位相角動摇の差となって現れるからである。

表 1 シミュレーション結果

Table 1. Simulation results.

\begin{tabular}{|c|c|c|c|c|}
\hline $\begin{array}{c}5-x \\
\text { No. }\end{array}$ & $\begin{array}{l}\text { 潮流 } \\
\text { 采統 }\end{array}$ & $\begin{array}{l}\text { 無対策眭の } \\
\text { 現象 }\end{array}$ & $\begin{array}{l}\text { 本安定化方式に } \\
\text { 上る解列台数 }\end{array}$ & $\begin{array}{c}\text { 最小 } \\
\text { 解列台数 }\end{array}$ \\
\hline 1 & $P_{1}$ & $G_{1}$ 加速貯誠 & $2 / 6$ (注) (1 pu) & $2 / 6(1 \mathrm{pu})$ \\
\hline 2 & $P_{2}$ & 安 定 & 0 & 0 \\
\hline 3 & $P_{3}$ & 安 定 & 0 & 0 \\
\hline 4 & $P_{4}$ & $G_{1}$ 扣速脱調 & $5 / 7(2.5 \mathrm{pu})$ & $5 / 7(2.5 \mathrm{pu})$ \\
\hline 5 & $P_{5}$ & 安 定 & 0 & 0 \\
\hline 6 & $P_{6}$ & $G_{1}$ 加速脱調 & $4 / 6(2 \mathrm{pu})$ & $4 / 6(2 \mathrm{pu})$ \\
\hline
\end{tabular}

(注) $a / b, a:$ 解列台数, $b$ : 運転台数

表 2 実規模モデル系統でのシミュレーション結果 Table 2. Simulation results using real power system model.

\begin{tabular}{|c|c|c|c|c|}
\hline $\begin{array}{l}r-x \\
\text { NO. }\end{array}$ & 運転台数 & 事故点 & $\begin{array}{c}\text { 本安定化方式に上る } \\
\text { 解列容量 (\%) }\end{array}$ & $\begin{array}{l}\text { 最小解列 } \\
\text { 容囬 }(\%)\end{array}$ \\
\hline 1 & \multirow{2}{*}{ 全台運転 } & $A ル ー ト$ & 67 & 67 \\
\hline 2 & & $B ル ー ト$ & 59 & 59 \\
\hline 3 & \multirow{2}{*}{1 台停止 } & Aルート & 54 & 42 \\
\hline 4 & & $B N-1$ & 42 & 34 \\
\hline 5 & \multirow{2}{*}{2 台停止 } & Aルート & 34 & 34 \\
\hline 6 & & 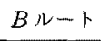 & 24 & 24 \\
\hline 7 & \multirow{2}{*}{3 台停止 } & $A ル-ト$ & 0 & 0 \\
\hline 8 & & $B ル ー ト$ & 0 & 0 \\
\hline
\end{tabular}

（2）ケース1とケース6の結果より, 本安定化方 式は, 主幹系統側の状態変化による安定度度合の変化 をも的確にとらえ，解列台数を算出していることがわ かる。これは仮想ノードSの位相角動摇を把挃する ことにより, 主幹系統の状態変化をとらえることがで きるからである。

また，表 2 は実規模モデル系統を用いたシミュレー ション結果で, 制御対象発電所门運転台数をパラメー 夕としたときの本安定化方式による解列容量(運転発 電機の合計容量に対する解列発電機の合計容量の比 率)と試行錯誤により求めた最小解列容量を示してい る。

このシミュレーション結果は, 2 ルート $(A ル ー$ ト, $B$ ルート)の長距離送電線(並行 2 回線)を介して 主幹系統に接続している 3 籄所の近接発電所を対象と したもので，これらの発電所は等価一機として取扱わ れている。また, 対象事故は, $A$ ルト, $B$ ルート の $6 \mathrm{LG}$ 主保護遮断事故(事故継続時間は 70 ミリ秒) である。

表 2 より，ケース $3 ， 4$ を除くすべてのケースで最 小解列容量と一致していることがわかる。また、ケー ス 3，4の過鄱制御量も解列台数にして1台であり, 十分な精度であるといえる。このほか系統構成や事故 点を変えて数十ケースのシミュレーションを行い方式 の有効性を確認した。

\section{5. 安定化システムの構成}

本システムは主幹系統に対して等洒一機とみなせる 一群の発電機を制御するもので方るが，一群の発電機 が必ずしも一電気所隹中しているとは集中限らない。例 えば，負荷の中心部から数百 $\mathrm{km}$ 離れた遠隔地で電気 的に近い場所に発電所が数籄所散在している場合, こ れらは等価一機発電機とみなすことができる。このと

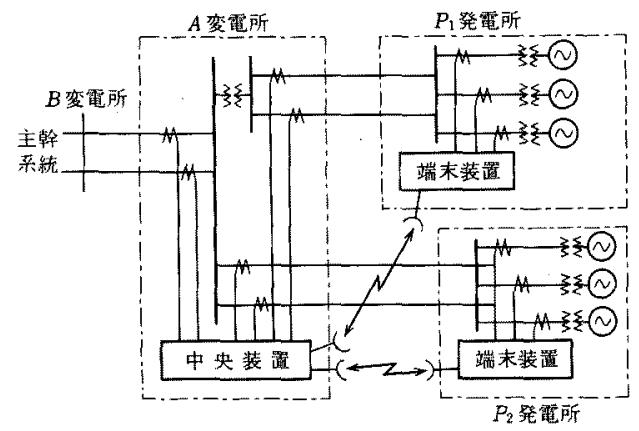

図 11 システム構成図

Fig. 11. System configuration.

T. IEE Japan, Vol. 112-B, No. 7, '92 
き, 本システムは各発電所に端末装置を設置し，制御 演算を実施する中央装置とは，デー夕伝送装置を用い て結合することになる。図11 は,このような実系統 に適用した例を示す。

図において，各発電所に設置された端末装置では発 電機端子の電圧, 電流から各発電機の電気出力を導出 し，中央装置に伝送する。系統事故は通常主保護卜り ップで70ミリ秒程度の事故継続時間が想定されるが, 本システムにおいて発電機の系統事故時の応動を正確 に把握するためには，この70ミリ秒間の発電機出力 を正しくシステムに取込む必要がある。このため, 発 電機出力は $300 \mathrm{~Hz}$ (電気角で $60^{\circ}$, 時間間隔で 3.3 ミ リ秒)でサンプリングされ，中央装置に伝送される。

伝送系に関しては, システムの動作時間上の必要性 から高速な伝送が要求される。伝送データ量に関して も，本システムでは複数個の $300 \mathrm{~Hz}, 12$ ビットの発 電機出力データおよび各種運転条件などを伝送する必 要があり，伝送速度 $54 \mathrm{~kb} / \mathrm{s}$ の高速伝送方式を採用し ている。

中央装置は $A$ 変電所に設置され, $A$ 変電所の母線 より主幹系統側の電流の総和值，母線電圧扔よび系統 側駆動点インピーダンスからディジタル演算により仮 想ノ一ドの電圧 $V_{s}$ を算出する。一方，母線より発電 機側の電流の総和值，母線電圧および現運用状態での 発電機全体の等価的内部インピーダンスから発電機側 の等価的内部電圧を演算し，平常時に抢ける両者の位 相角の差を求めておく。位相を求める演算のため，系 統の電圧, 電流は $600 \mathrm{~Hz}$ (電気角で $30^{\circ}$ )でサンプリン グされる。脱調判定のための演算は，系統の動摇を発 電機出力総和值の変化により検出して起動する。系統 動摇発生後の発電機位相角は，機械入力に等しい事前 の発電機出力と起動後の発電機出力の差を積分するこ とにより得られる。事前の発電機出力は，系統の微小 な動摇による影響を受けないように十分平滑された值 を用いる。

1 秒程度で脱調する現象を安定化させるためにシス テムに要求される動作時間は，系統事故発生から 250 ミり秒以内である。このため，系統動摇発生後に系統 の電圧, 電流データからリアルタイムで脱調を予測 し，発電機制御を判定する演算部は非常に高速の演算 が要求される。発電機出力のサンプリング間隔が 3.3 ミリ秒であるから，位相角演算，脱調予測などの基本 的な演算はすべてこの 3.3 ミリ秒の間に完了される。

系統に大きな擾乱が発生し発電機の脱調が予測され た場合, 中央装置で演算された最適制御の結果に従い 必要な発電機はトリップされる。発電機の制御指令は
伝送路の下りルートを使い高速に端末装置に伝送され る。各端末装置では自端情報のみで判断できる電力変 化娭出要素をフェイルセイフ要素としてもち, 中央装 置から伝送されるトリップ指令とAND 条件を構成す ることにより，誤動作を防止して信頼度を向上させて いる。

保護りレーによって約 70 ミり秒で事故が除去され た後, 安定化システムは事故除去の確認, 過渡現象の 消去時間，ディジタルフィルタの時間遅れなどで約 40 ミリ秒経過した後の 60 ミリ秒間に観測した状態量 を用いて 250〜260ミリ秒の将来時点の動摇を予測し て脱調判定を行い，安定化に必要な発電機の解列台数 を決定する。その後，トリップ信号の伝送遅延時間， $\mathrm{CB}$ の開極などのために要する約 80 ミリ秒後に発電 機が解列される。結局，事故発生から発電機解列まで の所用時間は約 250 ミリ秒である。

本システムは系統脱調を防止するという重大な機能 をもつ。このため全系は 2 系列化し，万一系統に大き な摄乱が発生した場合システム不動作には至らないよ うに配慮している。

\section{6. 安定化システムの総合動作試験}

開発した安定化システムの総合動作試験を $3 \mathrm{kV}$ 模 擬送電系統を用いて行った。複数の系統構成を設定 し，発電機出力や事故条件を変えて数十ケースの試験 を行った。その結果，すべてのケースで最適な応動結 果，すなわち，あらかじめ調べた解列台数と一致した 結果が得られた。これにより，開発した安定化システ ムが過渡值流分や高調波を含んだ実現象でも的確に応 動することが確諗された。

図 12 に試験系統の一例を示す。 $30 \mathrm{~kW}$ の発電機 2 台で制御対象発電所を模擬し，120kW の発電機 2 台 で主幹系統を模擬している。図 13 は，この系統を用 いた試験結果の一例であり，Aルートの $1 L ， 2 L の$

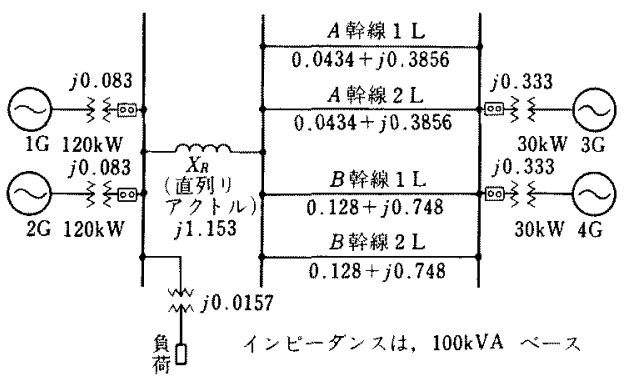

図 12 模擬送電系統の試験采統

Fig. 12. Simulation circuit on the high power simulator. 


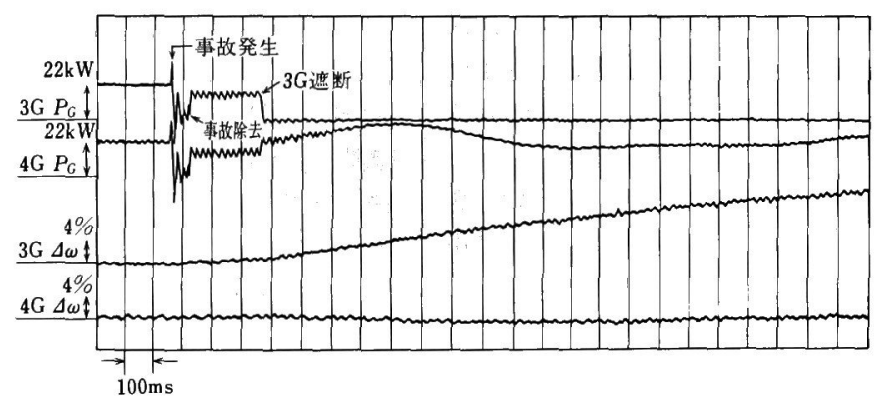

図 13 試験結果

Fig. 13. Test result.

同時 $3 \mathrm{LG}$ 主保護遮断事故である。このケースは, 安 定化システムがないと, 対象発電所を模擬する 2 台の $30 \mathrm{~kW}$ 発電機が脱調するケースである。図 13 からわ かるように,この現象に対して安定化システムは, $30 \mathrm{~kW}$ 発電機 1 台を解列し, 系統を安定化している。

\section{7.むすび}

大容量電源が主幹系統から遠方に建設された電力系 統における脱調現象は, 特に電源線に事故が発生した 場合, 大容量発電所の発電機群の位相角が他の発電機 群に対して相対的に大きく進み, 脱調に至るパターン である。この場合, 一部の発電機を高速に解列するこ とにより大容量の脱調に進展することを防止できる。 そこで, 事故発生前後の大容量電源の発電機出力と発 電機近端の母線電圧, 線路電流を高速にサンプリング し, 発電機内部電圧と系統側の仮想ノードの電圧との 位相角差の相対的な動摇を把握することにより, 脱調 予測と最少台数の発電機解列をする新しいオンライン 安定化方式とシステム構成, 機能について述べた。

この方式によれば, 電源側の発電機の出力, 電源線 の電流, 母線電圧など大容量電源近端で観測できる量 のみを用いて動摇の把握, 脱調判定, 解列する発電機 台数が決定できるために，通信網を含めコンパクトな 安定化システムを作ることができる点が長所である。 また, 本方式の有効性はシミュレーション・模擬送を 用いた試験で確認した。

最後に,この開発に御援助・御協力をいただいた東 京電力(株) と(株) 東芝の多くの方々に感謝します。 (平成 3 年 11 月 22 日受付, 同 4 年 2 月 6 日再受付)

\section{文 献}

（1）大浦・松沢・大塚・佐藤・津久井・小俣：「動摇中のオンラ イン情報による高速安定化方式」, 電気学会電力技術研資, PE-85-12 (昭 60)

（2）佐藤・津久井・小俣：「電力系統の動摇把握を基にしたオン
ライン高速安定化方式とアルゴリスム」, 電学論 $\mathrm{B}, 104$, 489 (昭 59-8)

（3）鈴木・㧕橋・富沢・合田・押田：「大容量電源系統のオンラ イン安定化制御方式の開発」, 電学論 B, 110，652 (平 2-8)

(4) S. D. Conte, et. al. : Elementary Numerical Analysis - An Academic Approach - (1980) McGraw Hill Co.

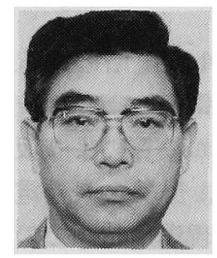

\section{大 浦 好 文 (正員)}

昭和 10 年 1 月 6 日生。 29 年福島工業 高校卒業。同年東京電力 (株)入社。 37 年電研 1 種合格。現在, 系統運用部にお いて, 系統保護制御システムの開発, 管 理, 系統技術に関する部門を担務。同部部長(制御システ 厶技術担当)。6 2 年電気学会論文賞, 平成元年同進歩賞受 賞。

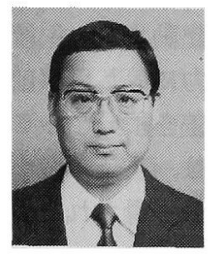

\section{鈴 木 守 (正員)}

昭和 24 年 5 月 12 日生。 49 年慶応義 塾大学大学院工学科修士課程修了。同年 4 月東京電力(株)入社。同社系統運用部 制御技術課において, 給電自動化システ ム, 電力系統保護制御システムの開発に従事。現在, 同課 課長。平成 3 年電気学会論文賞受賞。

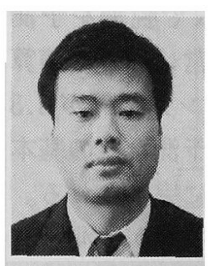

柳 橋健（正員）

昭和 30 年 8 月 13 日生。 55 年 3 月静 岡大学大学院工学研究科修士課程修了。 同年 4 月東京電力 (株) 入社。水力発電設 備の保守, 系統運用業務を経て, 系統運 用部制御技術課において系統保護制御システムの開発に従 事。同課副長。平成 3 年電気学会論文賞受賞。 


\section{佐 藤 正 弘 (正員)}

昭和 21 年 1 月 16 日生。 43 年 3 月東 北大学電気工学科卒業。同年 4 月 (株) 東 芝入社。電力系統の信頼度監視, 系統安 定化方式などの研究に従事。 53 年アメ リカ・Purdue 大学より MSEE。工学博士。 50 年電気学会 進歩賞受賞。

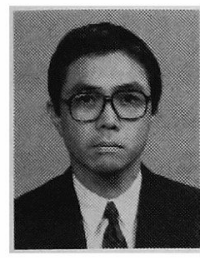

\section{津 久井良一（正員）}

昭和 24 年 3 月 8 日生。 46 年 3 月早稲 田大学理工学部電気工学科卒業。同年 4 月(株)東芝入社。主として, 電力系統保 護制御システムの開発などに従事。現 在, 電力系統技術部系統保護制御グループ課長。

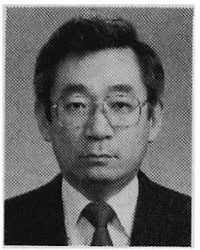

松 島 哲 郎 (正員)

昭和 23 年 2 月生。 46 年 6 月, 東京大 学工学部電気工学科卒業。同年 7 月東京 芝浦電気[現, (株) 東芝]入社。以後, 府 中工場にて保護継電装置の設計, ディジ タルリレーの開発, 系統安定化装置の開発などに従事。現 在に至る。

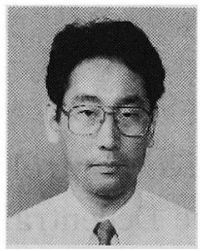

小俣 和 也（正員）

昭和 30 年 6 月 19 日生。 55 年 3 月早 稲田大学大学院理工学研究科修士課程修 了。同年 4 月 (株) 東芝入社。以来, 重電 技術研究所にて, 主として電力系統の監 視・制御方式の研究に従事。 